Journal of Ocean Engineering and Technology 27(5), 82-87, October, 2013

http://dx.doi.org/10.5574/KSOE.2013.27.5.082

\author{
북극해에서 계측된 국부 빙하중에 대한 선속 및 빙두께 영향 \\ 이탁기* · 이종현* · 임채환** • 최경식*** \\ *경상대학교 해양과학대학 조선해양공학과, 해양산업연구소 \\ **한국기계연구원 기계시스템안전연구본부 시스템신뢰성연구실 \\ ***한국해양대학교 해양과학기술대학 해양공학과
}

\title{
Effects of Ship Speed and Ice Thickness on Local Ice Loads Measured in Arctic Sea
}

\author{
Tak-Kee Lee*, Jong-Hyun Lee*, Chae-Whan Rim** and Kyungsik Choi ${ }^{* * *}$ \\ *Department of Naval Archi. and Ocean Eng., Gyeongsang National University, Institute of Marine Industry, Tongyoung, Korea \\ **Koreay Institute of Machinary and Materials, Daejeon, Korea \\ ***Department of Ocean Engineering, Korea Maritime and Ocean University, Busan, Korea
}

KEY WORDS: Local ice loads 국부 빙하중, Ship speed 선속, Ice thickness 빙두께, Icebreaker 쇄빙선, Arctic sea 북극해

ABSTRACT: The icebreaking research vessel ARAON conducted her second ice trial in the Arctic Ocean during the summer season of 2010. During this voyage, the local ice loads acting on the bow of the port side were measured using 14 strain ganges. The measurement was carried out during icebreaking while measuring the thickness of the ice every $10 \mathrm{~m}$. The obtained strain data were converted to the equivalent stress values, and the effects of the ship speed and ice thickness on the ice load were investigated. As a result, it was found that a faster speed produced a larger stress, according to the variation in the peak values below an ice thickness condition of $1.5 \mathrm{~m}$. Meanwhile, the effect of the ice thickness on the ice load was not clear.

\section{1. 서 론}

빙해지역을 운항하는 선박에서 해빙(Sea ice)에 의해 선체구조 가 받게 되는 빙하중은 선박이 해빙과 접촉하면서 받게 되는 힘 을 말하며, 선체 전체의 거동을 해석할 수 있는 전체 빙하중(Global ice load).과 국부 구조의 거동해석을 할 수 있는 국부 빙하 중(Local ice load)으로 나눌 수 있다. 이와 같은 빙하중의 구분 은 해빙에 의한 외부 하중을 받았을 때 선체구조의 거동을 구분 하는 방법이기도 하다. 즉, 국부 빙하중은 선체 외판 및 그 주변 부재에 직접 작용하여 구조 손상을 유발시키며, 전체 빙하중에 의 해서는 선체 전체가 하나의 구조부재로 거동한다고 볼 수 있다. 이러한 빙하중을 정확히 산정하는 작업은 쇄빙선박 설계에서 무엇보다 중요하다.

본 연구에서는 우리나라 최초의 쇄빙연구선인 아라온호를 이용 하여 2010년 8월 북극해에서 해빙의 재료강도 특성 시험과 쇄 빙 시 선수선측부의 국부 빙하중 계측 실선시험을 수행하였다. 이 시험은 쇄빙대상인 일정 규모 이상의 빙판을 선정하고 그 빙판
의 두께를 포함한 해빙의 특성값들을 실측한 후 쇄빙하면서 좌현 선수선측부 외판 내측에 부착된 스트레인 게이지를 이용하여 빙하중을 계측한 것이다.

본 논문은 북극해에서 수행된 실선 계측 시험 결과를 토대로 계 측된 빙하중과 선속 및 빙두께의 상관관계에 대한 분석을 시도한 것이다. 일반적으로 빙하중의 크기에 영향을 미치는 인자로는 쇄빙모드, 해빙의 재료 특성, 선박의 크기, 선수 형상, 추진 마력, 빙두께, 빙과 선박의 상대속도, 빙과 선체의 접촉 모드 등이 고려 대상이 될 것이다. 여기서는 계측된 빙하중에 대한 선속과 빙두 께의 영향을 분석하고자 하였다.

\section{2. 이전의 실선 계측 자료에 대한 분석}

\subsection{Polar Sea호(St. John et al., 1990)}

미국 해안경비대 소속 쇄빙선인 Polar Sea호를 이용한 1982년 Beaufort해에서의 실험에서 112 개의 이벤트 데이터가 계측되었다. 이 데이터는 Fig. 1과 같이 선박의 충격 속도와 피크 압력으로

\section{Received 30 May 2013, revised 30 August 2013, accepted 10 October 2013}

Corresponding author Chae-Whan Rim: +82-42-868-7415, cwrim@kimm.re.kr

(c) 2013, The Korean Society of Ocean Engineers

It is noted that this paper is revised edition based on proceedings of KAOST 2013 in Jeju. 


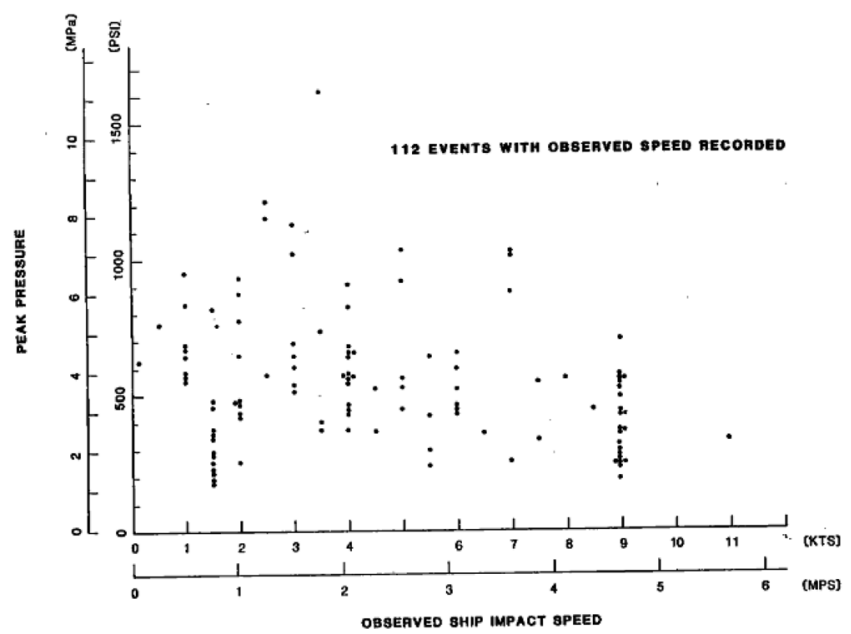

Fig. 1 Highest average pressure on a single sub-panel vs impact speed for the Beaufort Sea data (Summer) (St. John et al., 1990)


Fig. 2 Influence of ship's speed upon ice pressure and contact area (Tsoy et al., 1998)

정리되었다. 이 데이터에 의하면, 선속 3.5 노트 $(1.8 \mathrm{~m} / \mathrm{s})$ 까지는 속도 증가와 함게 빙압력이 증가하고 있으나, 3.5 노트 $(1.8 \mathrm{~m} / \mathrm{s})$ 이 상의 속도에서는 빙압력이 오히려 감소하고 있다. 그들은 대부 분의 충격 쇄빙이 3.5 노트 $(1.8 \mathrm{~m} / \mathrm{s})$ 근처에서 이루어지며, 높은 속도는 빙판이 얇거나 깨진 빙편 속에서 선박이 운항할 때 얻 어진다고 분석하였다.

\subsection{Lgarka호, Super Kapitan Danilkin호(Tsoy et al., 1998)}

러시아에서는 SA-15급 쇄빙상선인 Lgarka호와 Super Kapi$\tan$ Danilkin호를 이용하여 1983년 7-8월에 무르만스크에서 베 링해협에 이르는 북극해 항로에서 빙하중 계측 시험을 수행하 였다. 그들은 그 결과를 분석하여 Fig. 2와 같이 선속과 빙압력 또 는 선속과 접촉 면적과의 관계를 범위로 정리하였다.
이 그림에 의하면, 선속이 약 $4 \mathrm{~m} / \mathrm{s}$ 에 이르기까지는 빙하중이 증가하지만, 그 이상에서는 완만해지거나 거의 증가하지 않고 있 다. 또한, 빙의 접촉 면적은 선속이 약 $2 \mathrm{~m} / \mathrm{s}$ 까지는 대체적으로 증 가하나, 그 이상에서는 증가율이 현저히 낮아짐을 알 수 있다.

\subsection{Nathaniel B. Palmer호(St. John and Minnick, 1995)}

미국의 다목적 과학연구선인 Nathaniel B. Palmer호를 이용 하여 남극의 겨울철인 1992년 8-9월에 빙하중 계측 시험을 수행 하였다. 이때, 선수부 측면, 선수부 바닥, 선측과 선미부 패널 등 4 곳에 계측장치를 부착하여 빙하중을 계측하였다. 시험을 수 행한 곳은 남극반도 근처 South Orkney 제도와 South Shetland 제도였으며, 총 796개의 충격 이벤트를 계측하였다.

그들은 Single sub-panel에서의 압력과 Hull panel에서의 빙 하중을 선속별로 정리하였는데, 이때 계측위치도 함께 고려하여 Figs. 3, 4와 같이 나타내었다. 이 데이터는 산포도가 심해 그 특 징을 쉽게 파악하기 어렵지만, 동일한 속도에서 볼 때 선수부 바 닥과 선미부 패널보다 선수부 측면과 선측에서 비교적 높은 값을 보이고 있음을 알 수 있다.

\subsection{St. Laurent호 (Frederking, 2000)}

캐나다에서는 St. Laurent호를 이용하여 1994년 7 9월에 베링 해협부터 북해의 스발바르제도까지 북극해를 항해하면서 선수 부, 선측 및 바닥부 패널에 스트레인 게이지를 설치하여 빙하중 을 계측하였다.

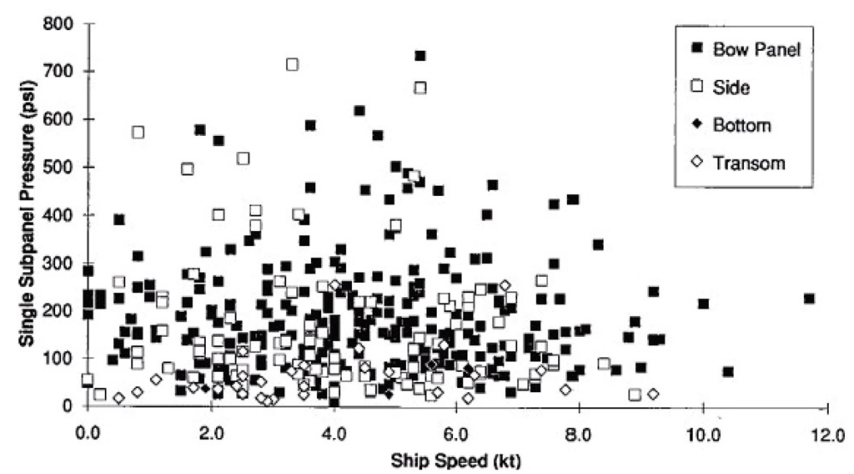

Fig. 3 Single sub-panel pressure vs. ship speed (St. John and Minnick, 1995)

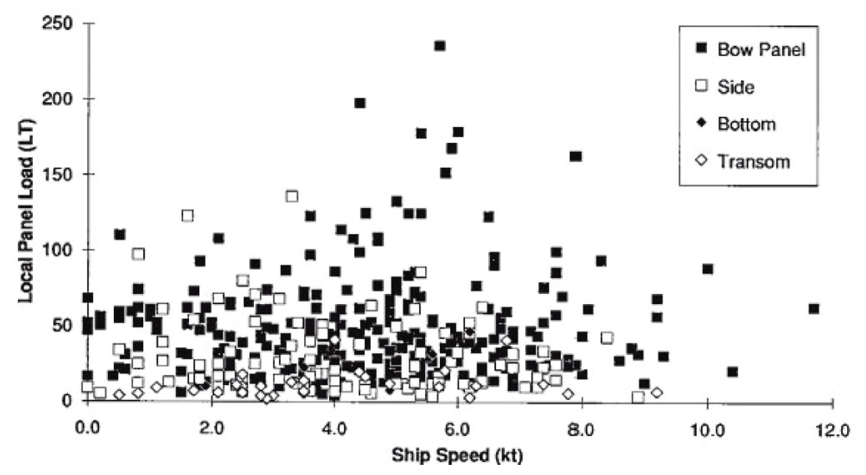

Fig. 4 Hull panel ice load vs. ship speed (St. John and Minnick, 1995) 




Fig. 5 Velocity effect on sub-panel pressure (Frederking, 2000)

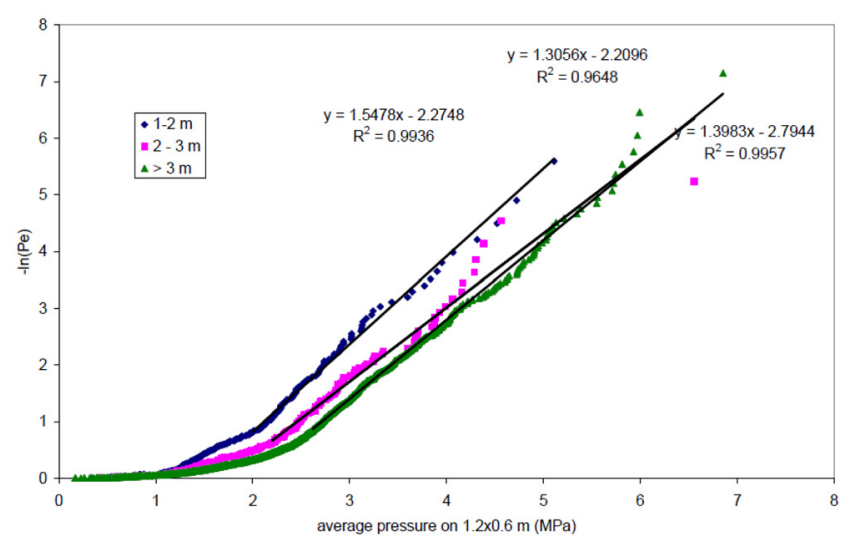

Fig. 6 Ice thickness effect on sub-panel pressure (Frederking, 2000)

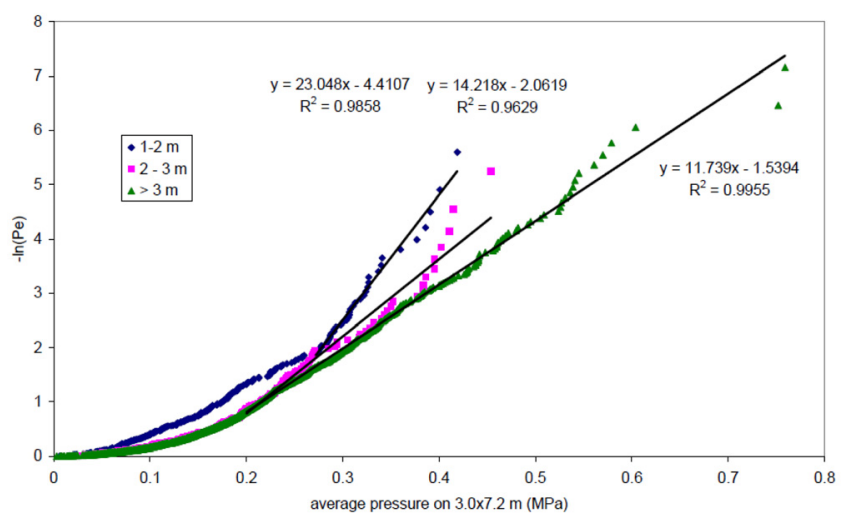

Fig. 7 Ice thickness effect on total instrumented area pressure (Frederking, 2000)

계측 결과를 토대로 Figs. 5 7과 같이 빙압력에 대한 속도 및 빙두께의 영향을 분석하였다. 그는 선속이 약 10 노트 $(5.1 \mathrm{~m} / \mathrm{s})$ 이하에서는 특별한 영향이 없으며 이를 넘으면 약 $20 \%$ 정도 보 다 높은 압력이 계측된다고 보고하였다. 빙두께의 영향에 대하 여는 서브 패널에서는 빙두께가 $1 \sim 2 \mathrm{~m}$ 인 경우는 $2 \mathrm{~m}$ 이상인 경 우보다 약 $1 \mathrm{MPa}$ 정도 낮은 빙압력을 보이고 $2 \sim 3 \mathrm{~m}$ 와 $3 \mathrm{~m}$ 이상 의 빙두께를 갖는 경우 그 빙압력은 거의 유사하다고 밝히고 있으며, 전체 패널에서는 빙두께가 증가할수록 빙압력도 증가

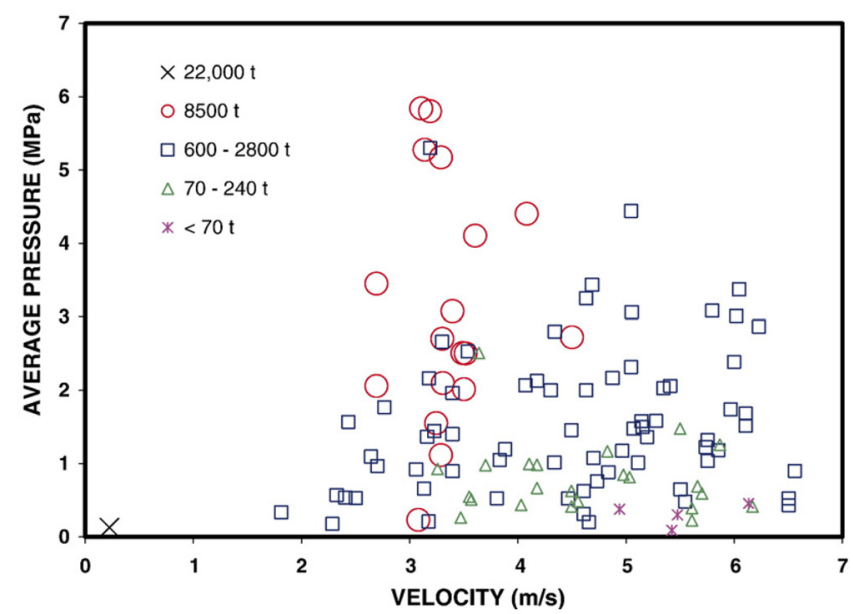

Fig. 8 Probability of average pressure on a "design" area of $0.33 \mathrm{~m}^{2}$ ( $0.46 \mathrm{~m}$ wide by $0.76 \mathrm{~m}$ high) on the Terry Fox (Ritch et al., 2008)

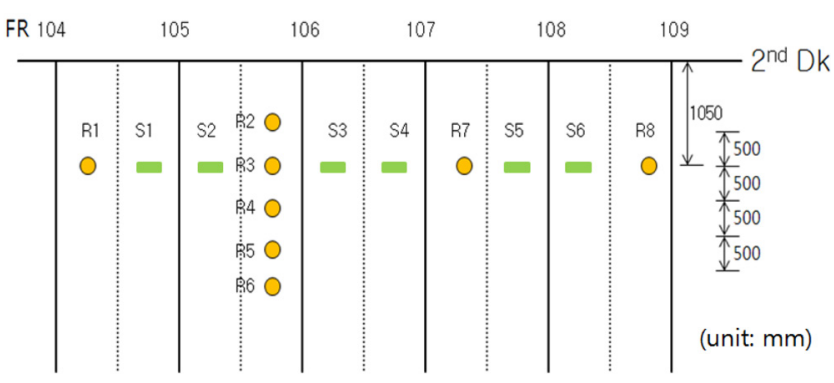

Fig. 9 Location of strain gauges

하는 경향을 보이고 있다고 분석하였다. 이때, 극값에 대한 통계 분석을 이용하여 압력을 분석하고 있다(Rim and Lee, 2007).

\subsection{Terry Fox호(Ritch et al., 2008)}

캐나다에서는 Terry Fox호를 이용하여 2001년 6월 Newfoundland 북동부 해안에서 실선시험을 수행하였다. 여기서 20 22,000 톤으로 추정된 빙산조각과의 178 회 충격이 관측되었으며 선속의 범위는 0.2 $6.5 \mathrm{~m} / \mathrm{sec}$ 이었다. 이에 따라 빙의 질량에 따른 선속 과 평균 압력과의 관계를 Fig. 8과 같이 정리하였는데, 그 분석에서 빙의 질량이 클수록 높은 압력을 보이고 있으나 속도 효과는 뚜렷하지 않다고 보고하고 있다.

\section{3. 북극해 빙하중 계측 자료 분석}

\section{1 빙하중 계측 개요}

빙해역을 쇄빙 운항시 선체에 작용하는 빙하중을 계측할 목 적으로 2010년 8월초 한국 최초의 쇄빙연구선인 아라온호를 이 용하여 선수부에 스트레인 게이지를 부착, 실선시험을 수행하 였다. 북극해 시험의 주요 목적으로는 해빙의 재료 특성 수집/분 석, 아라온호의 쇄빙성능 검증 및 빙하중 계측 등이며, 총 4 회에 걸친 쇄빙 시험이 실시되었다. 연구팀은 쇄빙 대상 빙판을 탐색한 후 그 빙판에 내려 계측 지점을 선정하고 빙판에 구멍을 뚫고 Ice gauge라는 줄자를 이용하여 빙두께를 측정하며, 빙시편을 추출 
하여 온도, 염도, 밀도, 압축강도 등을 포함한 빙특성을 계측하 였다(Park et al., 2011; Kim et al., 2012). 또한, 빙특성 및 두께를 계측한 빙판에 대하여 쇄빙 운항하면서 빙하중을 계측하고 쇄빙 성능도 확인하였다. 쇄빙성능 확인을 위해 선속, 추진마력, 대기 온도, 풍속 등에 대한 자료도 수집하였다(Kim et al., 2011).

빙하중 계측을 위한 스트레인 게이지는 Fig. 9에서 보이는 바와 같이 6 개의 1 축 게이지와 8 개의 로제트 게이지를 선수 Thruster room 내의 좌현측 외판 내부에 부착하였으나, 실제 계측시에는 이용 가능한 앰프 채널의 제약으로 총 24 개 채널의 신호만을 측 정하였다. 그림에서 알 수 있듯이, R8이 선수에 가장 가까운 게 이지이며, Fr. 109 위치에서 선수 쇄빙 Knife edge가 있고 제2갑 판의 수직선상 위치는 7,100 A/B이다.

이번 항해에서는 시험 대상 빙판을 선정하고 빙두께를 계측한 후 쇄빙하면서 빙하중을 계측하는 과정을 총 4 회에 걸쳐 수행 하였으나, 본 논문에서는 4 회 시험 중 빙두께를 계측한 경로를 매우 잘 맞추어 진행된 3차 시험시에 계측된 빙하중 자료만을 분석하였다. Fig. 10은 1회 시험시 빙판 상에 예상 쇄빙항로로 표시한 것이며, Fig. 11은 전자기 장비를 이용하여 빙두께를 계 측한 경로를 사진 상에 표시한 것인데, 두 계측선 모두 일직선임 을 알 수 있다. 빙두께 계측은 이러한 표시선을 따라 일정 간격으 로 수행하고 실제 쇄빙시험 수행 시 빙판 위에 표시된 예상 주 행코스를 맞추기 위해 노력하게 되며, 그럴 경우 선박의 운항궤 적이 거의 직선을 유지하여야 할 것이다.

Fig. 12는 3차 시험의 선박 운항 경로를 위도와 경도를 기준으 로 표시한 것이다. 그림에서 직선은 실제 선박 운항 궤적에 대한 직선의 추세선이며, 마름모로 표시된 것이 본선의 GPS(Global positioning system)로부터 계측된 선박의 실제 운항 경로이다. 그림에서 알 수 있듯이 이 시험시 선박의 운항 경로는 거의 직선 에 근접해 있음을 알 수 있다. 또한, 직접 시험을 수행한 연구자들 의 보고(Choi et al., 2011)에 따르면, 1차 시험은 예비시험 성격 이며, 2 차 시험에서는 폭이 상대적으로 좁아서 그리고 4 차 시험 에서는 빙판의 두께와 강도가 예상보다 훨씬 커서 빙판 위에 표 시된 예상 주행코스를 유지하기가 힘들었다고 기록하고 있으나, 3 차 시험에서는 예상된 주행거리를 비교적 정확하게 운항할 수 있었다고 한다. 따라서 3차 시험이 계측된 빙하중과 빙두께와의 상관성을 파악하기에 적합한 시험으로 판단하였다.

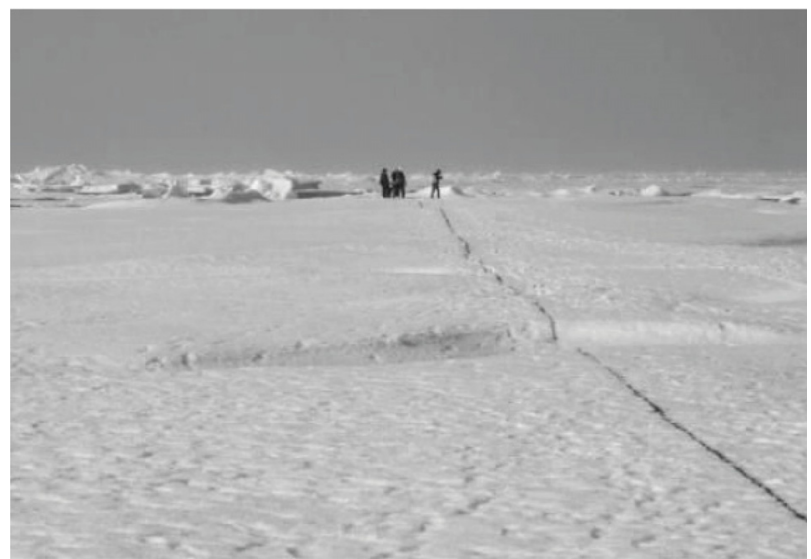

Fig. 10 Marked track line on ice floe at \#1 test (Kim et al., 2011)

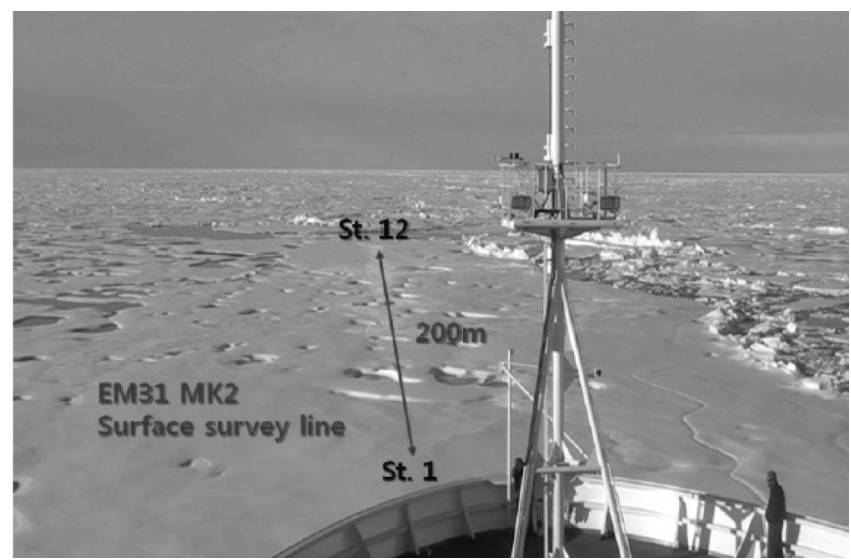

Fig. 11 Measuring distance on \#3 ice floe by EM31 (Kim et al., 2011)



Fig. 12 Trajectory of ice trial on \#3 ice floe

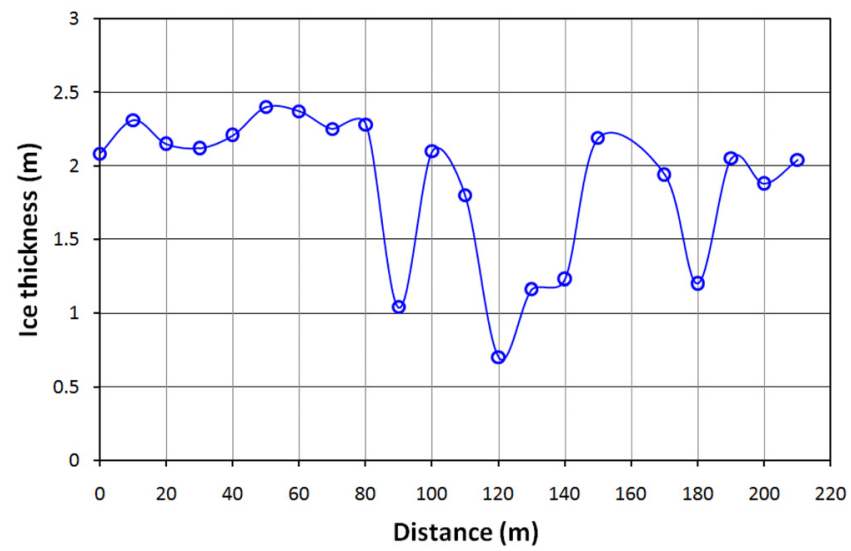

Fig. 13 Measured ice thickness (Aug. 4, 2010)

\section{2 빙두께 및 선속 계측}

빙두께는 Fig. 13에서 보이듯이 대상 빙판 상에서 연구자들이 직접 계측하는 방법을 택하였고, 예상 쇄빙경로 선정 후 전체 빙판을 $10 \mathrm{~m}$ 간격으로 나누어 계측하였다(Park et al., 2011).

선속의 경우 본선의 GPS 데이터로부터 시작점과 끝점의 위 도, 경도 좌표를 이용해 거리를 계산하고 이동시간으로 나누어 속도를 구하였다. Fig. 14은 쇄빙 시험시 계산된 선속을 기준으 


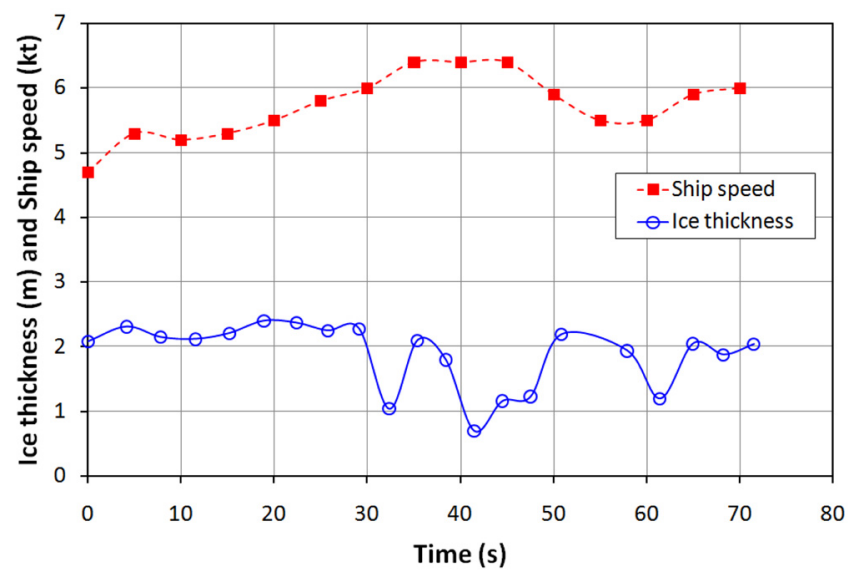

Fig. 14 Lap times at each locations for ice thickness measurement based on ship speed (3rd test)

로 각 구간별로 속도와 시간의 곱을 누적시켜 구한 거리를 이 용하여 각 빙두께 계측 지점의 통과시간을 연속적으로 나타낸 것이다. 이는 빙하중 계측자료와 빙두께의 상관관계를 파악하 기 위해 각 데이터를 동기화시키기 위한 작업이다.

\section{3 계측된 빙하중에 대한 빙두께 및 선속 영향 분석}

본 시험에서 계측된 빙하중을 등가 응력 기준으로 정리하고 계 측된 시간대를 고려하여 선속별, 빙두께별로 분류한 후 그래프로 나타내면 Fig. 15, Fig. 16과 같다.

Fig. 15는 선속에 따른 등가 응력을 빙두께로 구간을 나누어 나타낸 것이다. 이 자료에서 선속은 5.25 노트 $(2.7 \mathrm{~m} / \mathrm{s})$ 에서 6.4 노트 $(3.3 \mathrm{~m} / \mathrm{s})$ 범위에서 피크 값이 나타났으며, 이에 대응하는 빙두 께는 $1.04 \mathrm{~m}$ 에서 $2.21 \mathrm{~m}$ 까지였다. 동일한 속도에 많은 데이터가 있는 것은 동시에 계측된 14 개의 게이지에서 피크가 나타나는 것을 모두 고려하였기 때문이다. 그림에서 알 수 있듯이 빙두께 가 $1.5 \mathrm{~m}$ 이하인 경우 선속이 증가할수록 계측된 등가 응력이 점 차 증가하고 있다. 반면, 빙두께가 $1.5 \mathrm{~m}$ 를 초과할 경우에는 선속 이 증가할수록 계측된 등가 응력은 작아지고 있다. 참고로, 아라 온호의 쇄빙성능은 굽힘강도가 $630 \mathrm{kPa}$ 을 초과하지 않는 $1.0 \mathrm{~m}$ 두께의 평탄 빙을 3 노트 $(1.54 \mathrm{~m} / \mathrm{s})$ 의 속도로 연속 쇄빙할 수 있는 수준이며, Kim et al.(2012)에 의하면 시험지역 해빙의 굽힘강도는 평균 $160 \mathrm{kPa}$, 최대 $340 \mathrm{kPa}$ 로 계산되었다. 이 값은 해빙의 온도, 염도 및 밀도를 계측하여 이로부터 굽힘강도를 경험식으로 계 산한 것이다.

빙하중에 대한 선속의 영향을 살펴보기 위한 위와 같은 분석은 그 동안 선속만을 고려한 빙압력이나 빙하중 비교에서 빙두께를 추가적으로 고려할 수 있도록 하였으며, 이로부터 빙두께가 $1.5 \mathrm{~m}$ 이하인 경우와 $1.5 \mathrm{~m}$ 를 초과하는 경우에 서로 다른 경향을 가지는 것으로 분석되었다. 이는 이전의 자료에서 발견하기 어려운 특 징이며, 특히 쇄빙시에 선속과 빙하중과의 관계를 좀 더 구체적으 로 파악할 수 있게 되었다.

Fig. 16은 빙두께의 변화에 따른 등가 응력을 선속별로 구간을 나누어 나타낸 자료이며, 특정 두께에 데이터들이 모여 있고 다 른 빙두께 구간에는 데이터가 너무 적어 그 경향을 일반화하기가

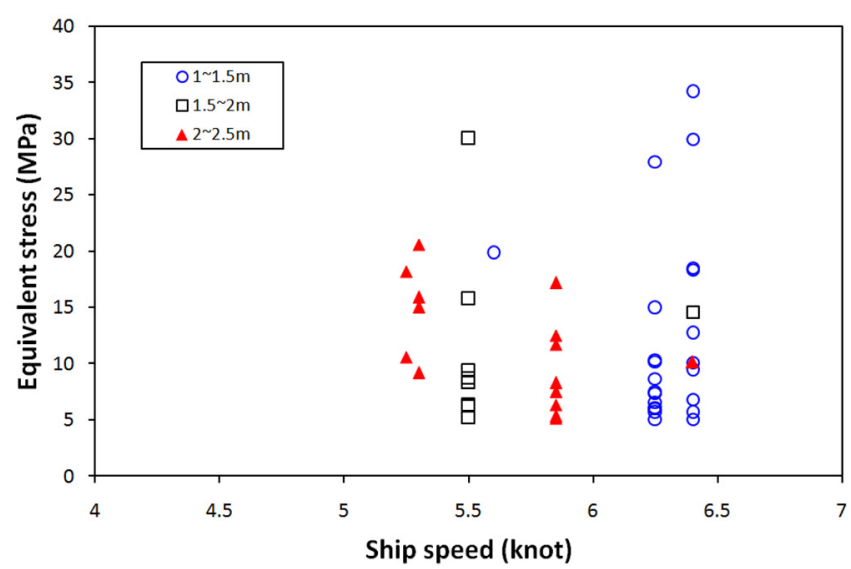

Fig. 15 Equivalent stress vs ship speed

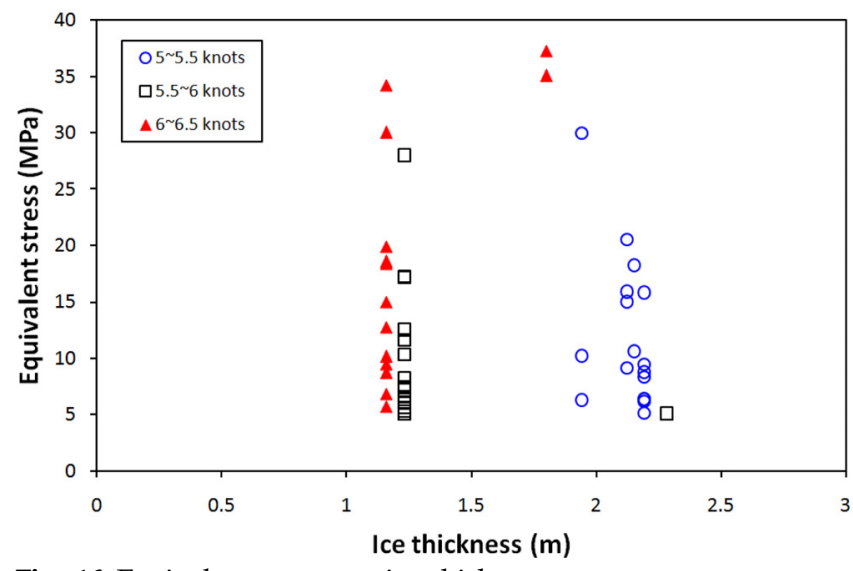

Fig. 16 Equivalent stress vs ice thickness

어려운 측면이 있다. 그러나 선속이 5 6노트(2.6 3.1m/s)인 구간 에서는 빙두 께가 두꺼워질수록 계측된 등가 응력이 다소 낮아지 고 있음을 알 수 있다. 한편, 선속이 6노트 $(3.1 \mathrm{~m} / \mathrm{s})$ 를 넘는 데이터 들은 빙두께가 조금 두꺼워졌는데도 불구하고 낮은 빙두께 때보 다 다소 높은 등가 응력이 나타나고 있는데, 이는 전반적으로 계 측지역 해빙의 강도 특성과 아라온호의 쇄빙성능을 고려할 때 발 생가능한 응답 범위인 것으로 판단되지만 순간적인 풍속 변화 등의 영향도 포함될 수 있으므로 일반화시키기엔 좀 더 많은 자료가 필요해 보인다.

빙하중에 영향을 미치는 인자들 중에 선속과 빙두께 이외에도 쇄빙 당시 선박의 추진마력의 영향도 배제할 수 없을 것이다. 다 시 말하면, 쇄빙 운항시 선박이 얼음을 잘 깨면서 전진한다면 추 진마력을 일정하게 유지하지만 그렇지 못할 경우는 추진마력을 높이는 등의 조치를 취하게 되기 때문이다. 그러나 본 3차 시험 에서 쇄빙구간의 추진마력은 우현의 출력이 좌현보다 약간 컸으 나 급격한 변화 없이 안정적으로 유지되었으며 그 평균치는 5,029 $\mathrm{kW}$ 이었던 것으로 보고된 바 있다(Kim et al., 2011).

\section{4. 결 론}

본 연구는 2010년 8월 북극해에서 수행된 쇄빙 성능 시험시에 
선수선측부에서 스트레인 게이지를 이용한 계측된 빙하중에 대 하여 시험 당시의 선속과 빙두께의 영향을 분석하고자 한 것이다.

시험은 대상 빙판을 결정하고 빙두께를 계측한 다음 쇄빙 운 항하면서 선속과 빙하중을 계측하는 순서로 진행되었다. 빙두께 계측자료와 선속을 동기화시키는 작업을 기초로 하여 빙두께 및 선속을 구간별로 그룹으로 묶고 이에 대응하여 선속 및 빙두께에 따른 빙하중의 크기를 고찰하였다.

분석 결과, 전반적으로는 데이터의 산포도가 높아 경향을 파악 하기 힘들었으나, 각 구간별 그 경향을 살펴보면, 빙두께가 $1.5 \mathrm{~m}$ 이하인 구간에서는 선속이 증가할수록 계측된 빙하중이 증가하 는 것을 알 수 있었으며, 그 이상의 빙두께 구간에서는 선속 증 가와 함께 계측된 빙하중이 오히려 감소하고 있음을 확인하였다. 이는 이전의 실선계측 자료에서도 언급하고 있듯이 (St. John et al., 1990), 높은 선속은 얇은 빙두께 영역에서 얻어지는 것이라는 분석이 가능하다. 한편, 선속을 유사한 범위로 묶어 살펴본 빙하 중에 대한 빙두께의 영향은 일반화 가능한 뚜렷한 경향을 찾기가 어려웠다.

본 분석에 이용된 자료는 쇄빙시 선수선측부에 작용하는 국부 빙하중을 선박 관련 핵심 파라메터인 선속과 빙 관련 핵심 파 라메터인 빙두께를 동시에 고려할 수 있는 소중한 자료라 생각 된다. 그렇지만, 기초자료로서 빙두께를 $10 \mathrm{~m}$ 간격으로 계측한 것 과 선속을 5 초 간격의 평균 속도로 계산한 점 등을 고려할 때 전 반적으로는 평균적인 경향을 파악한 것으로 이해해야 하는 제 약이 따른다. 추후 유사한 계측이 수행된다면, 빙하중에 영향을 미칠 수 있는 파라메터로서 풍속이나 추진마력의 순간적인 변화 등이 보강되어야 할 것으로 보인다.

\section{후기}

본 연구는 지식경제부 지원 산업원천기술과제 (Grant No. 10033640)의 연구비 지원으로 수행된 연구결과이며, 연구비 지원에 감 사드립니다.

\section{References}

Choi, K.S., Lee, C.J., Rim, C.W., Kim, H.S., 2011. Strength Characteristics of Arctic Sea Ice from Ice Field Tests of the Icebreaking Research Vessel ARAON. Journal of the Society of Naval Architects of Korea, 48(3), 254-259.
Fredering, R., 2000. Local Ice Pressures from the Louis S. St. Laurent 1994 North Pole Transit. NRC, Canadian Hydraulics Centre, Technical Report HYD-TR-054.

Kim, D.H., Park, Y.J., Choi, K.S., 2012. Material Properties of Arctic Sea Ice during 2010 Arctic Voyage of Icebreaking Research Vessel ARAON: Part 2-Compressive Strength, Flexural Strength and Crystal Structures. Journal of Ocean Engineering and Technology, 26(1), 1-8.

Kim, H.S., Lee, C.J., Choi, K.S., Kim, M.C., 2011. Study on Icebreaking Performance of the Korea Icebreaker ARAON in the Arctic Sea. International Journal of Naval Architecture and Ocean Engineering, 3, 208-215.

Park, Y.J., Kim, D.H., Choi, K.S., 2011. Material Properties of Arctic Sea Ice during 2010 Arctic Voyage of Icebreaking Research Vessel ARAON: Part 1-Sea Ice Thickness, Temperature, Salinity and Density. Journal of Ocean Engineering and Technology, 25(2), 55-61.

Rim, C.W., Lee, T.K., 2007. Estimation of Ice Load on Bow of a Icebreaking Research Vessel. Journal of the Society of Naval Architects of Korea, 44(5), 509-516.

Ritch, R., Frederking, R., Johnston, M, Browne, R., Ralph, F., 2008. Local Ice Pressures Measured on a Strain Gauge Panel during the CCGS Terry Fox Bergy Bit Impact Study. Cold Regions Science and Technology, 52, 29-49.

St. John, J.W., Daley, C., Blount, H., 1990. Ice Loads and Ship Response to Ice -Summer 1982/Winter 1983 Test Program. Report No. SSC-329, Ship Structural Committee.

St. John, J.W., Minnick, P.V., 1995. Ice Load Impact Study on the National Science Foundation's Research Vessel Nathaniel B. Palmer. Report No. SSC-376, Ship Structural Committee.

Tsoy, L.G., Karavanov, S.B., Glebko, Y.V., Barabanov, N.V., Babich, N.G., Karlov, V.K., Shatsberger, E.M., 1998. Collection of SA-15 Operations Data. INSROP working paper 107. 